Nika CIGOJ

Davorin GAZVODA

\section{The changing appearance of single-family house settlements in Slovenia: Comparative analysis of settlements in Ljubljana, Maribor, and Novo mesto}

\section{Introduction}

The urbanization of quality Slovenian cultural landscapes, especially increased construction in the Karst region, has provoked a variety of polemics among both the lay and professional publics. Plans to develop the Karst which have been revealed in recent new proposals are strongly incompatible with existing structures, especially as regards existing villages and towns. What we have here is not only the urgent need to preserve quality village and town centres and suitably revitalize the countryside, but also, unfortunately and above all, the extremely unsuitable basic proportions and criteria of new projects that fail to consider the over-all spatial context in which they are proposed. Inappropriate or low-quality construction not only affects the individual structure itself but the whole image of the city, suburb, and landscape in which it is built, and undermines the appearance of the entire Slovenian space. The acceptable number and size of land parcels and buildings, over-all density, basic urban standards, and the organization and design of traffic infrastructure are all fundamental concepts which need to be defined, developed, and ultimately accepted as unambiguous construction standards as soon as possible. Such concepts will not only place limits on developers but will have the purpose of guaranteeing a certain kind of development: specifically, high-quality urban development and architecture that includes the design of open spaces within and around residential areas to round off and soften their appearance. Detailed comparisons of settlements of single-family houses built in Slovenia during the last forty years will be useful in the effort to address this problem, the purpose being to determine to what extent the basic proportions and organization of clusters of single-family dwellings in various settlements and cities have changed during this period.

Today in Slovenia, stand-alone houses remain the most popular kind of single-family dwellings. The planned construction of single-family houses (that is the number of actual building units) is currently too few to create larger independent settlements with their own complex organization, traffic flows, communal infrastructure, and open spaces that would encircle what is ultimately a small city. The reduced size of the land area dedicated to new construction has an influence on the overall appearance of settlements, the arrangement of units in settlements, and the appearance of the wider space in which settlements are built. The annexation of new smaller building settlements to older traditional settlements, especially in the countryside, presents problems at the outset. The smaller the area, the more difficult it is to guarantee a whole complex system of formation with its own specific characteristic within the organization of the settlement in the wider surroundings, whether architectural or natural. With many smaller residential areas, divided one from the other, it is more difficult to guarantee the unity and connection of the whole. The planning and design of individual units in a city or settlement influences its overall appearance. In other words, it is not only architecture that creates the city space. The quality and appearance of the city space will also be affected by the representation, function, and design of the open space that surrounds the building tissue. Especially crucial to the quality of life in residential areas is the inclusion of planted areas and green surfaces throughout the living area. This element plays an important role not only in spatial design, but also in socio-psychological and ecological aspects.

If ten years ago the areas for the construction of new residential areas were larger, so too were the shares in them dedicated to open spaces. The space between individual units was larger and the planning of the infrastructure network more rational. The entire blueprint allowed for larger individual units and also offered a higher quality living space.

\section{Overview of the construction development of single-family houses in Slovenia from 1950 until 2000}

After 1950, organized or planned settlements of single-family houses began to appear in Slovenia. This type of construction was meant to guarantee a certain level of quality in the surroundings of residential neighbourhoods, in the sense of providing open spaces and transportation links as well as interactions between buildings and gardens and individual housing units within a settlement. Planned or regulated construction was intended to halt the spontaneous emergence of stand-alone single-family dwellings and increase the residential quality of new settlements. It would ensure the more rational use of land, the more harmonious architectural appearance of settlement as a whole, and would also attempt to meet the expectations of society and the needs of the construction profession.

The housing shortage of the post-war era was addressed after the 1950s with the construction of settlements of multifamily apartment buildings. This is one reason that the typology of single-family houses tended toward the unregulated and unplanned construction of houses by individual owners. New legislation was passed after 1950 that replaced centralized management with the system of self-management. At the same time, the professions were lobbying for improved conditions. At this time, the first modern single-family houses began to be built in Slovenia using spatial and technological innovations (Koselj, 2005). Following the social and economic reforms of 1965, family dwellings were reclassified from social goods to market goods; this reclassification led to an extraordinary surge in the construction of single-family houses (Ivanšek, 1998). The habit of constructing one's own house led to many 'black' construction sites without the proper registration or permits. These dwellings were often built in areas where 
development had not been anticipated. This led to socially, spatially, and economically wasteful construction especially on the peripheries where "land was in free circulation and when mortgage loans were not available. Such illegal constructions eventually acquired 'owner's rights'"' (Bojovič, 1984: 5).

The Studio for Residential Dwellings and Fittings (an independent institute founded by France Ivanšek in 1963) created a special expert group to do research, documentation, planning and advising work with the intention of improving the quality of the construction of single-family units (Ivanšek, 1998).

Conditions for single-family houses began to improve at the beginning of the 1970s when the organized construction of single-family dwellings, mostly row houses, began to be undertaken. These dwellings, contrary to units in apartment buildings, were more suitable for the individual development of families in the framework of their own home. With the growing awareness of issues regarding quality residential surroundings, a larger part of the population began to show a desire to live in areas that had a closer connection to natural elements.

At the end of the 1980s, residential construction slowed markedly as a result of worsening economic conditions. The passage of new residential housing legislation related to development activities, changes in land ownership laws, and the preparation of a National Residential Housing program at the beginning of the 1990s opened the way for the comprehensive transformation of residential housing construction. Unfortunately, numerous high-quality development plans did not suit free market conditions in the newly-emerged transitional society, and because of this, these newly-planned residential settlements were adjusted downward at least from the standpoint of quality. At the same time, a shortage of appropriate land for development began to be apparent. The discrepancy between supply and demand only increased. With the new differentiations emerging in society, the attitude toward construction changed.

In this regard, conditions for the construction of single family houses in the mid-1990s were similar to those of the 1960s, that is to the period prior to the rise of social and professional efforts to improve the quality of residential environments. The most frequently constructed family dwellings remained stand-alone single-family houses. Construction by owner (independent construction) was less common because of changed economic conditions, and yet the situation for organized single-family house construction was still in disarray. The same kind of problems that had been written about in the literature of the past reappeared (Krušec and Žaucer, 1996).

Despite the high price of land and other difficulties in construction, the single-family house remained the ideal for most Slovenians. This was confirmed by the research study of Quality housing and residential surroundings starting in 2002 and conducted by the Urban planning institute which analysed public opinion polls taken between 1969 and 1994 by the Public Opinion and Mass Communication Research Centre (Šašek-Divjak et al., 2002). The results of this analysis indicate that more than half of the people polled $(68.9 \%)$ already lived in their own houses. Those that lived in others types of multi-family dwellings but would prefer to live in a single-family house was $93.4 \%$ (most recent poll conducted in 1986). Data regarding the trends in residential planning were also captured in the poll entitled Development-Research Project conducted by the Faculty of Social Science in Ljubljana (Mandič et al., 2006) which tracked housing conditions and trends among Slovenian households. The analysis concluded that the most important feature of residential dwellings for those polled was peaceful and green surroundings (75\%). Ninety-four percent of those polled identified this feature as important. The second most important feature of residential dwellings was identified as good neighbourly relations and third place was taken by independence from other households. Eighty percent of those polled said that guaranteed parking was important, $70 \%$ said it was important to have their own garden or atrium. The proximity of recreational areas did not rate as high, though it was still considered important by more than half of those polled (53\%).

\section{Work method}

The presented comparative analysis of single-family house settlements in Ljubljana, Maribor, and Novo mesto ${ }^{[1]}$ includes clear examples of planned developments of stand-alone, row, and atrium houses, and duplexes that have reached various phases of construction. The analysis uses data from the land and building registers of the individual municipalities as of May 2007, the most recent aerial photo taken in the individual cities, as well as older topographical and aerial photo plans and land surveys. The settlements selected include the most important official construction sites during the given time frame and is a sufficiently representative sample for analysis.

For the purpose of this comparative analysis, selected settlements were divided into areas depending on their character and function in the specific settlement: land (common gardens, buildings, residential gardens), surface area dedicated to automobiles (street, parking, garages), footpaths, open spaces with defined purposes (playgrounds, sports fields, other recreational and social areas), and other open spaces (tree-lined and planted areas, green buffer zones...). For each settlement, data was selected from the land register and arranged into tables. The information was also graphically presented using the above-mentioned definitions of surface types as well as building type, settlement, city, and period of construction.

The appearance of the settlement - settlement image - was determined by its structure (the number and variety of various spatial elements, not just the units themselves but infrastructure and open spaces) and the characteristics of the defined features and elements. In order to compare settlements in the three Slovenian cities, more detailed measures were defined to determine the condition and quality of housing settlements in the last forty years:

- size of settlement

- number of units belonging to various defined building types,

- relationship between units and other areas in the settlement,

- average size of parcel (house and garden) by building type,

- proportion between paved/built areas and gardens 


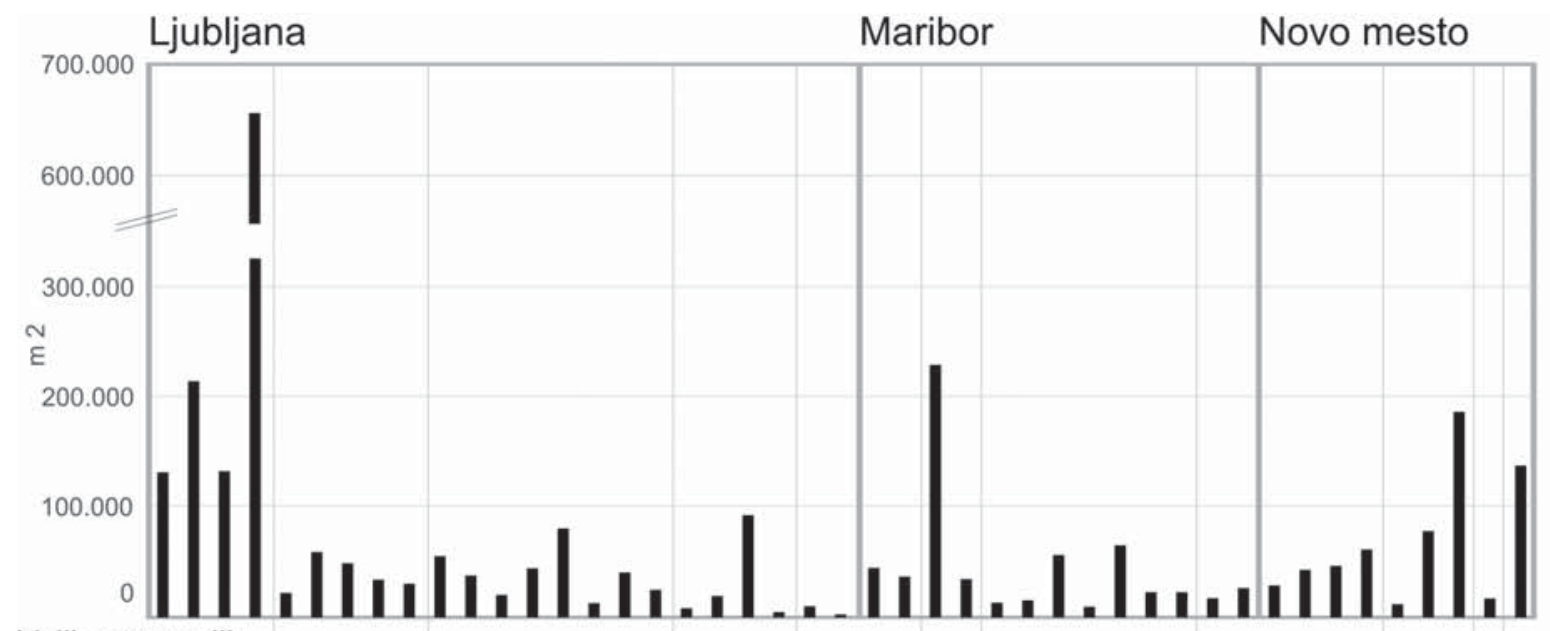

Velikost naselij

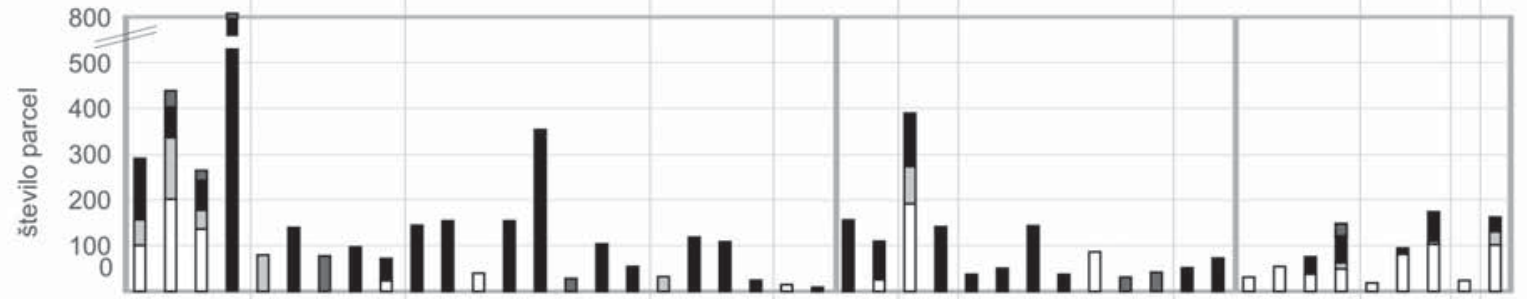

Število parcel v naseljih

] prostostoječa h. [ h. dvojček vrstna h. [atrijska h.

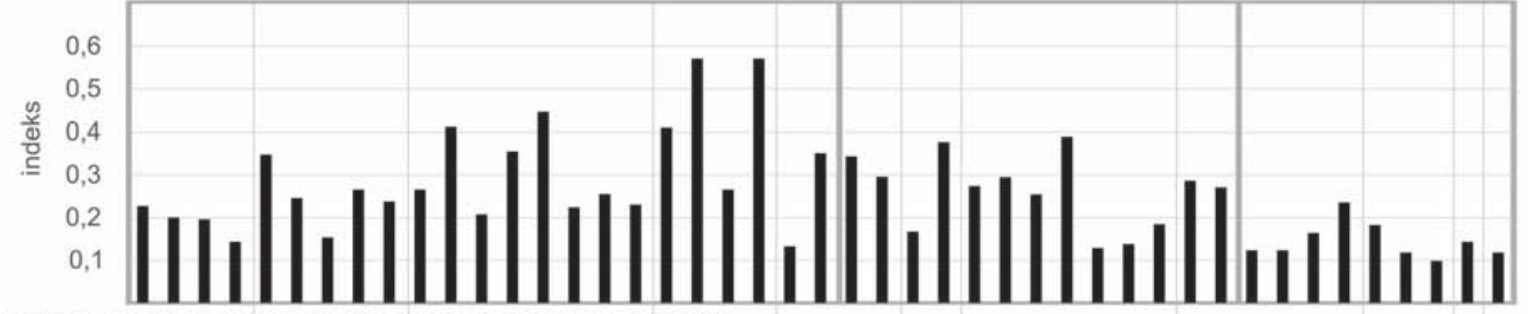

Odnos med površino in številom parcel po naseljih

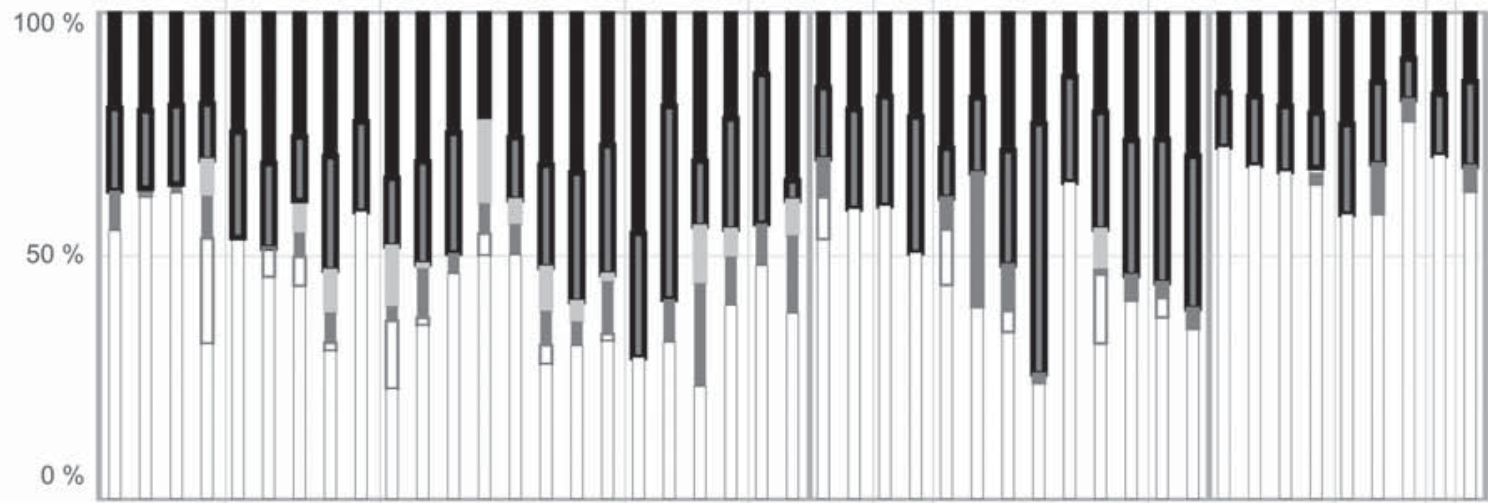

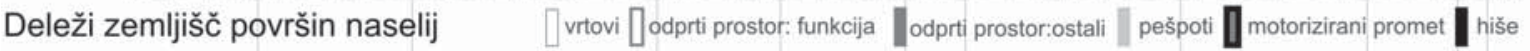

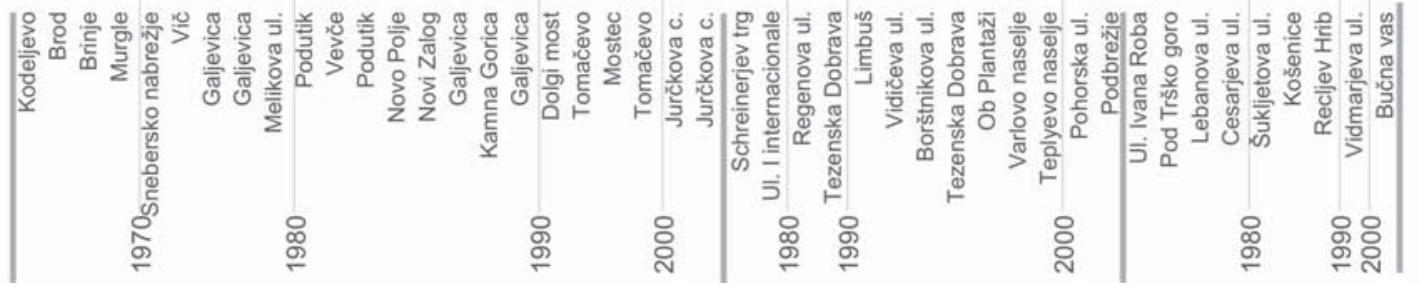

Figure 1: Graph of settlement size, number of parcels in the settlement, built areas and common areas in settlements by city, and time period. 
- portion of land dedicated to common gardens, houses, and residential gardens,

- portion of land dedicated to defined areas in the settlements and also by: building types (stand-alone houses, duplexes, row houses, atrium houses) constructed in settlements and cities over a ten-year construction period,

- infrastructure areas: areas dedicated to automobile traffic (streets, access roads, parking places, garages...), walking and bicycle paths, garbage collection areas, other infrastructure,

- open spaces with defined functions (children's playgrounds, sports areas, other recreational areas, areas for relaxing and socializing),

- other open spaces (green buffer zones, tree-lined paths and streets, planted areas at the edges of settlements),

- special open spaces (parts of the wider natural system).

\section{Results and interpretation of comparative analysis of single-family house settlements in Ljubljana, Maribor, and Novo mesto}

\subsection{Characteristics of single-family house settlements that have an influence on over-all spatial image}

Comparisons with older single-family house settlements in Ljubljana and Maribor indicate that the portion of open spaces in new settlements has decreased and the space between buildings has been reduced almost by half. The area dedicated to streets and gardens has also diminished. On average, the size of land parcels has decreased by a third. The area dedicated to common gardens and other shared open spaces has decreased by half. In terms of the defined criteria, only Novo mesto deviates from the average. During the period being studied, the size of land parcels in Novo mesto have remained roughly the same, likewise the surface area of the settlements, density, the uses of land parcels, and the amount of open space.

It was determined that the use and quality of residential garden space was dependant on the development plan for the settlement as a whole. In terms of similar qualities of individual houses, they are influenced by the mutual connection of group of houses and other elements in the settlement. It appeared that one of the main determinants of quality in a residential environment was the quality of the plan for internal and external space. The planning of each of these components cannot be undertaken independently of the other but must be developed in a coordinated fashion.

What was most remarkable was the reduction of the overall surface area of residential settlements. A larger surface area makes it possible to design distinct clusters of dwellings, whereas it is more difficult for smaller projects to acquire their own individual features. In addition, there is no transitional space between the individual dwellings and the external surroundings. Along with the reduction in overall surface area, there has been a reduction in the number of units built. Individual closed settlements, planned and constructed as

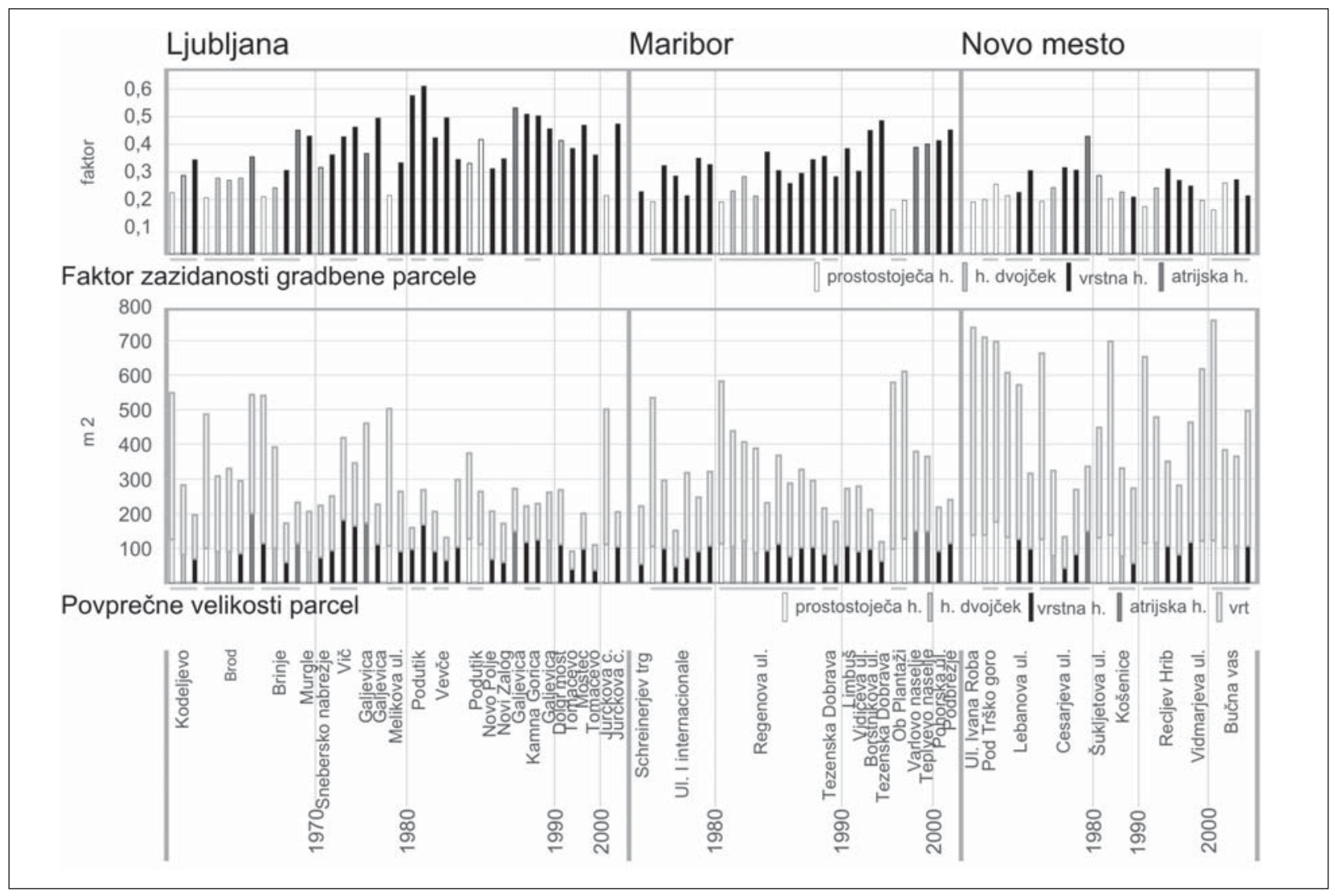

Figure 2: Graph of building density in construction parcels and average size of parcel by building type, city, and time period. 
organized developments and built before 1970, had from 200 to 450 parcels in an enclosed settlement (Murgle had over 800 ). Since that time, settlements with a range from 80 to 150 parcels have prevailed. The newest settlements have between 30 and 60 parcels. It is also clear that the newer settlements contain only one type of unit; mixed and varied settlements are no longer built.

Settlements in Ljubljana and Maribor are dominated by row houses. These are followed by atrium houses and duplexes. Settlements of stand-alone houses are the least frequent. In Novo mesto, in contrast, stand-alone houses have been the most frequent building unit throughout the more than forty year period.

What is notable over the time period is the increase in the number of units as well as the increased density of construction on a given surface area. Ljubljana has a higher level of building density in settlements with an average of 0.282 , more units per settlement of surface area than Maribor with an average of 0.262 , or Novo mesto with an average of 1.283. This is understandable given the higher price of land in the capital. Throughout the time period under studied, Novo mesto has had a lowest builder density per settlement than Maribor and Ljubljana and a higher quality of space and appearance.

Regardless of the time period or location, parcels for standalone single-family houses take up the greatest amount of surface area. They are followed by atrium houses, duplexes, and row houses which take up the smallest surface area. The size of the garden is also dependant on the unit type: with atrium houses having the smallest gardens.

The greatest fluctuations in average parcel size per house and garden in the last forty years has taken place in Ljubljana (houses from 70-170 $\mathrm{m}^{2}$, gardens from 80-400 $\mathrm{m}^{2}$ ). Since the 1970s, there has been a decrease in the average parcel size and an increase in the size of the houses, resulting in a decrease in garden size. In the mid-1980s, garden size saw a marked decrease (in Ljubljana from 150-400 $\mathrm{m}^{2}$ to $115-150 \mathrm{~m}^{2}$ ) although the size of houses did not experience a commensurate increase. In Maribor, the surface area of parcels for houses has remained relatively constant throughout this period regardless of building type, while the average surface area of gardens has fallen. The situation is entirely different in Novo mesto where parcels are generally much bigger than in Ljubljana or Maribor and the size of all types of housing units has remained relatively constant throughout the period. After 1990, the average surface area of gardens actually increased.

In accordance with the decreased size of land parcels discussed above, the increased floor plan for houses, and the reduced surface area dedicated to gardens, the building density factor per parcel is the highest in Ljubljana (between 0.205 and 0.616 ) and lowest in Novo mesto (between 0.158 and 0.433 ). In Maribor, the factor vacillates between 0.160

\section{1

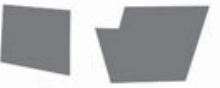 1970

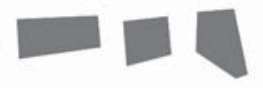 1980 $\square \square \sqrt{1990}$ $\Delta \square=2000=$}

Figure 3: Scheme of the size of a number of analysed settlements in Ljubljana and Maribor by time period.

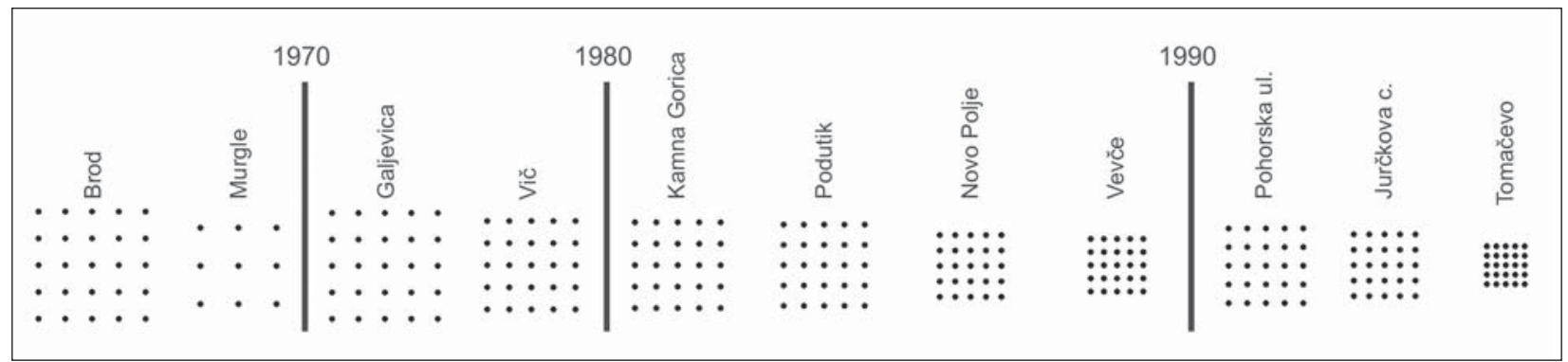

Figure 4: Scheme of building density - increased number of units on a given surface area.

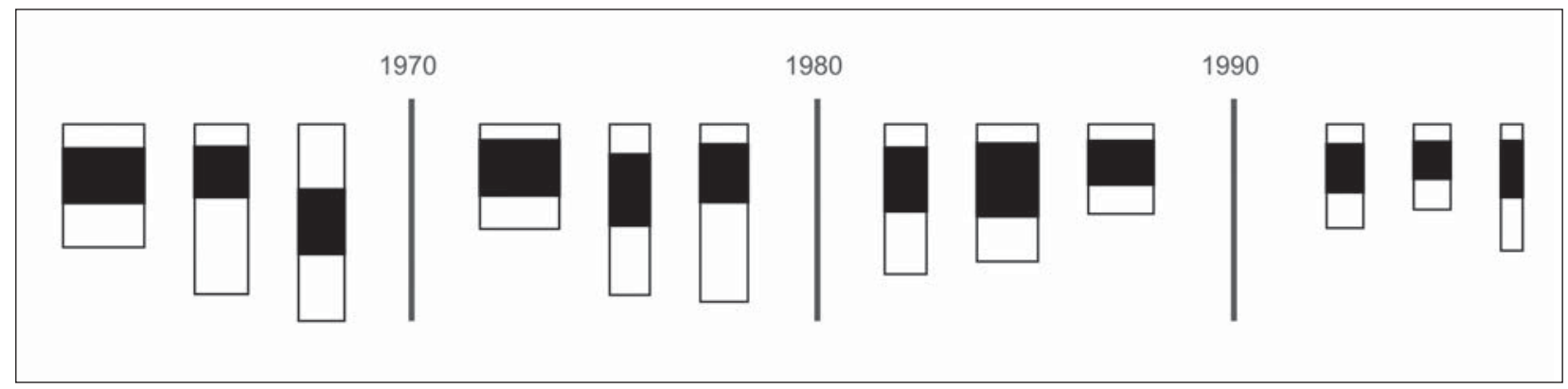

Figure 5: Scheme of decreasing parcel size for row houses in Ljubljana and Maribor by time period. 
and 0.488 . The building density factor per parcel in certain new settlements has increased by half as compared to older settlements.

In recent years, fewer settlements are constructed that stop traffic at the periphery and where the area between individual housing units is furnished with footpaths. Certain older settlements have an organization plan whereby access is provided to common parking areas and garages (usually at the beginning and end of a housing cluster, less often in the middle) and these traffic/parking areas comprise the divisions between the housing clusters. Most newer settlements are organized in such a way that cars can drive up to each individual entrance and to the parking garage of the complex. The consequence of this organizational structure is much more surface area dedicated to automobile traffic. In such settlements, more of the common surface area is taken up by streets and less by footpaths and other paved areas. Although streets and roads in the new settlements (both for automobiles and pedestrians) are wider (5-10 meters for streets, 3-5 meters for footpaths) than in the older settlements (4-8 meters for streets, 1-2.5 meters for footpaths), in the older settlements the corridors beside streets and paths were much more generous, often planted with trees and common green spaces.

\subsection{Design of streets and open spaces in single-family house settlements}

The purpose of open spaces in a settlement of single-family houses is above all to provide houses with surrounding gardens and to guarantee the specificity of development and function in individual residential units. The organization of the settlement in terms of residential and common gardens is dependent on building density and the distance between units. Decreasing the surface area for gardens and/or increasing the elevation of the buildings leads to higher density and vice versa. Open spaces such as streets, parking areas, paths, planted areas, tree-lined areas, and other green spaces for recreation, games, and socializing can compensate for smaller distances between units and give the entire settlement its own character and improve the quality of living conditions. A larger settlement is able to have, both inside and on its outer edges, more public and semi-public spaces. The proportion of common open spaces with defined functions (children's play areas, sports areas, other recreational areas, places for socializing...) is greater in older settlements (10-20\%). In newer settlements, in contrast, the green areas are mostly greenbelts between settlements for the exclusive use of the settlement. The development of other street areas and treelined paths has been abandoned. Above all, the amount of collective open areas in new settlements is determined by the standard of the settlements. In settlements with minimal standards, common open spaces are scarce (tree-lined paths, planted areas, playgrounds ...) In above-standard (or luxury) settlements, green areas and open spaces are more ample. Residential settlements in Novo mesto have the highest proportion of collective garden areas (between 60 and $70 \%$ of total settlement surface area), the lowest proportion of built-up land (between 10 and $25 \%$ ), and the lowest proportion of surface area dedicated to automobile use (between 10 and $15 \%$ of total settlement surface area). Residential settlements in Ljubljana have the lowest proportion of collective garden areas (between $25 \%$ and $40-60 \%$ of total settlement surface area). The situation is similar in Maribor, though settlements with upwards of $40 \%$ collective garden area predominate.

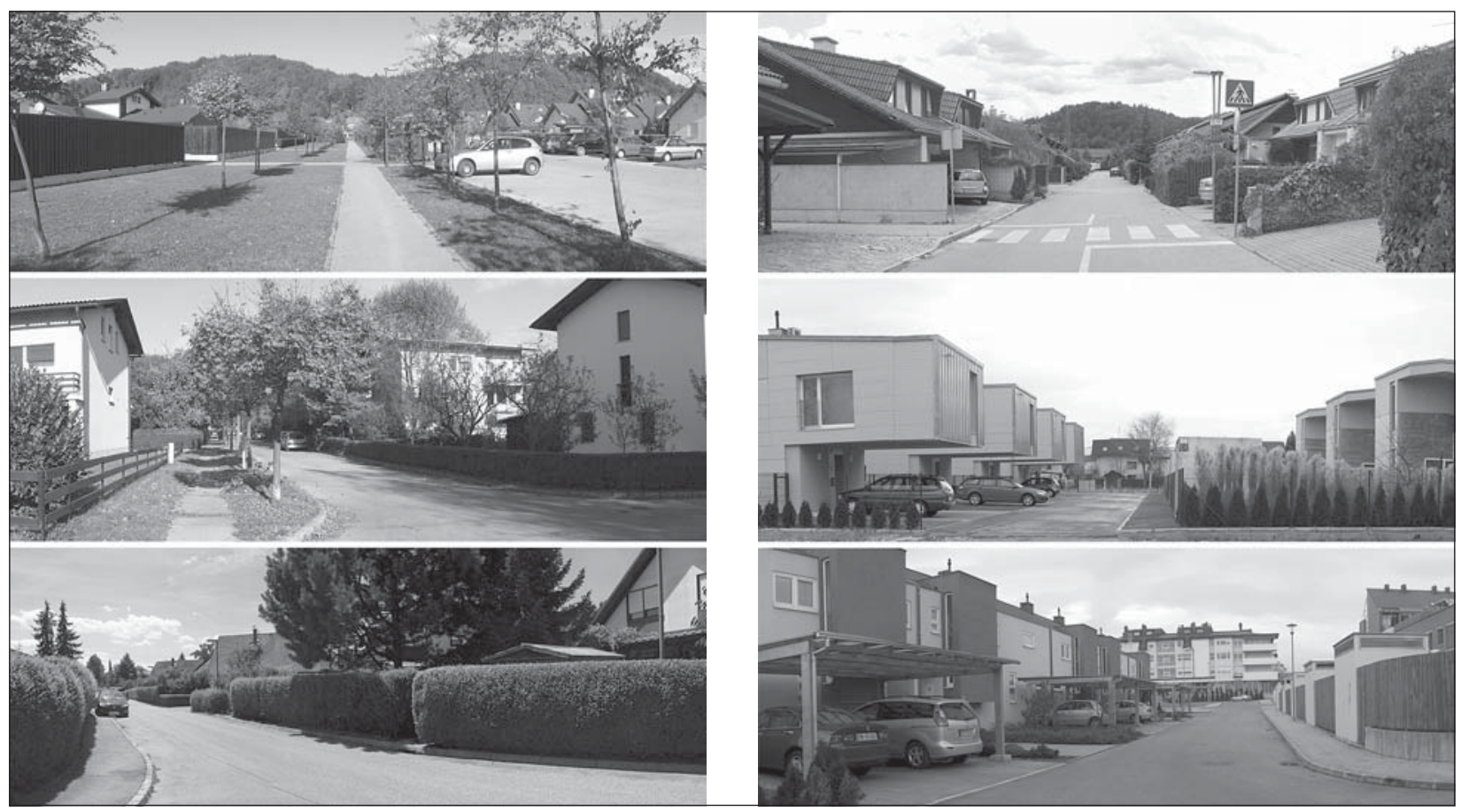

Figure 6: Streets dedicated to automobile traffic. The examples on the left are from older settlements where the streets are wider and have planted edges. The examples on the right are from new settlements, where streets are narrower, construction is denser, and there are almost no trees. (Photos: Nika Cigoj) 
In addition to the building density of the parcel, the image from the street is influenced by the proportions of the buildings, their width and above all their height. While one-storey units predominated in older settlements, newer settlements almost always use houses two storeys or higher. The distance between units has decreased by almost half of the total length of paths and gardens (Tomačevo $d=2.8 \mathrm{~h}$, Murgle $d$ $=5 \mathrm{~h}$, Podutik $\mathrm{d}=3.2 \mathrm{~h}$, Kamna Gorica $\mathrm{d}=4.2 \mathrm{~h})^{[2]}$. The situation is somewhat different in settlements with higher standards where the dimension of gardens are similar to those of older settlements and the distance between units is similar to lower standards because of $\mathrm{P}+1$ housing units (Jurčkova cesta $\mathrm{d}=0.89 \mathrm{~h}$, Pohorska ulica $\mathrm{d}=2.7 \mathrm{~h}$ ). In addition to building size, the organization of the street space in the settlement has an influence on the area between units. In new settlements, not only has building density increased and the size of the parcel decreased, but the space for streets is also much more constricted. As far as quality of life is concerned, those settlements that have greater distances between units and additional open spaces in the street themselves (tree-lined streets, for example, and planted areas that also improve the microclimate of the settlement) tend to be more congenial. In general, plantings in new streets are fewer and tree-lined streets have been almost entirely abandoned as a practice.

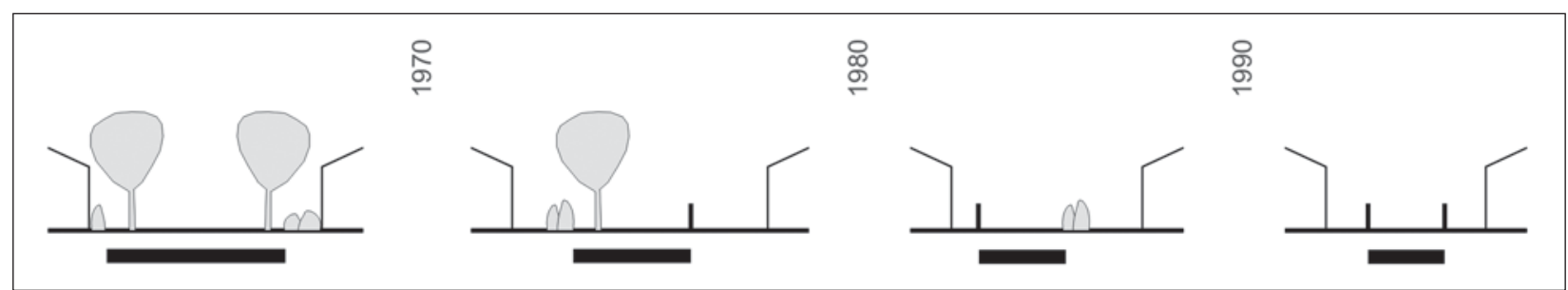

Figure 7: Scheme of street space in Ljubljana and Maribor during the period under studied.
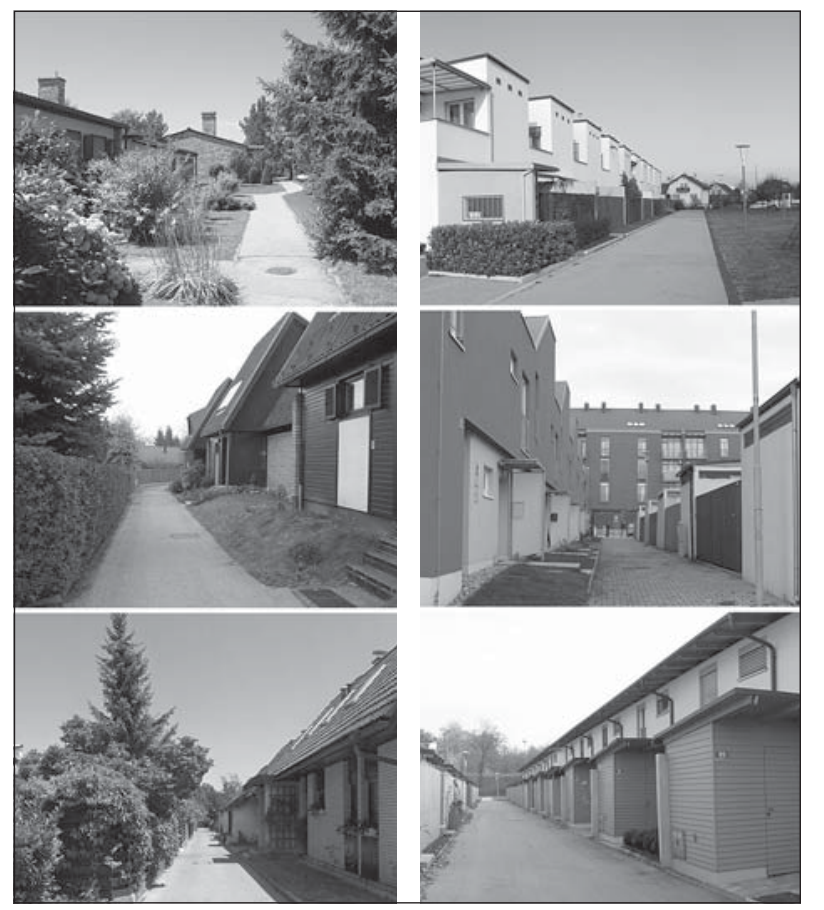

Figure 8: Street space and footpaths. In older settlements, footpaths were a part of the overall landscaping of the space (see examples on the left). New solutions decrease the size of these paths to a minimum (see examples on the right). (Photos: Nika Cigoj)
What is left is the minimal space for street and the sidewalk next to it.

In terms of connecting paths, or paths within smaller settlements, the appearance from the street is dependant largely on the arrangement and specifically how many green planted areas are integrated into the street profile. The width of front gardens also has a direct impact on the appearance from the street. In recent decades, the width of footpaths and front gardens has decreased by nearly half. In newer settlements with higher standards, the width of front gardens and foot paths has widened, but this additional space has been gained at the expense of sidewalks and streets. Thus the border between public and private has been blurred which is even more notable where streets are narrow.

In the majority of new settlements, it is not possible to discern an integrated landscape design of the open spaces. The design function is limited to ensuring the minimal required elements for the settlement to function (pavement, benches). Only very few settlements even have organized areas for the collection of garbage and similar functions. Areas that are used on a daily basis are larger and are generally centrally located within the settlements and are thus only accessible to the inhabitants of the settlement. How these areas are arranged and their size influences the level of their use. Smaller areas, regardless of their location within settlements, tend to be used less for additional activities. These areas are directly influenced by the surrounding buildings

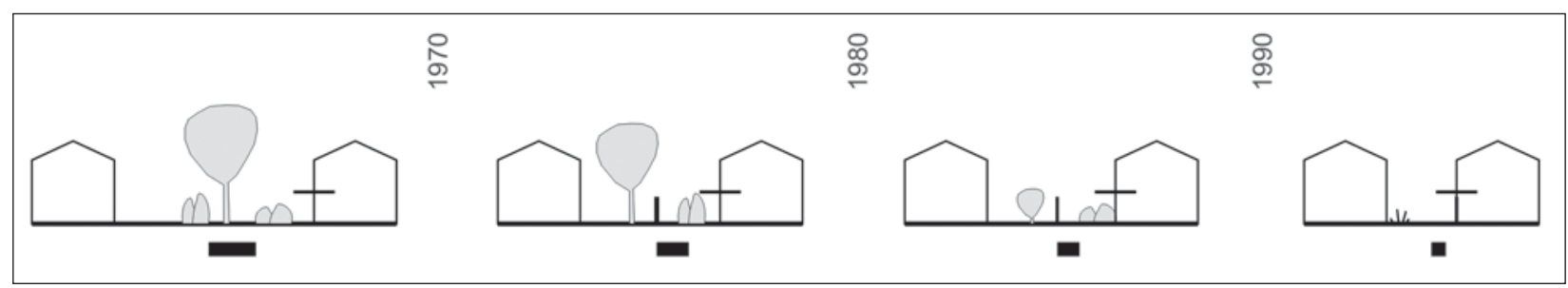

Figure 9: Scheme of street space and footpaths in Ljubljana and Maribor by time period. 

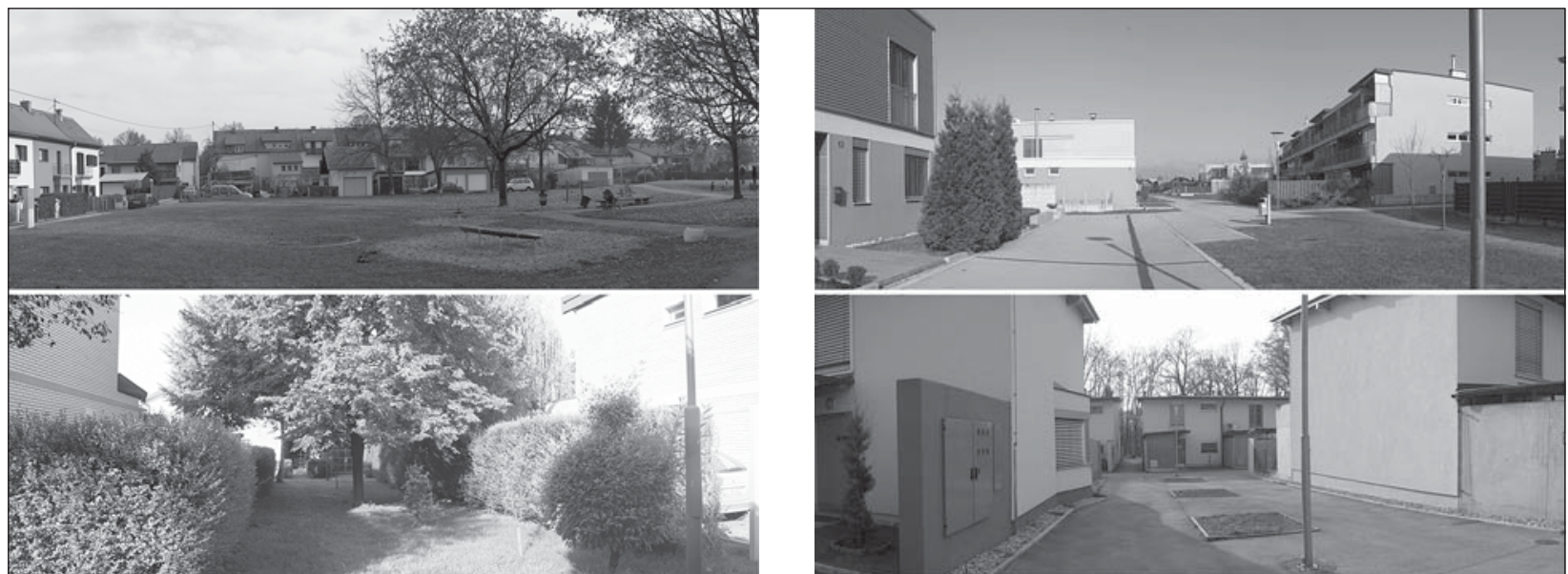

Figure 10: Common open spaces in settlements of single-family houses. In older settlements, common open areas are planted and are used for socializing, games, and recreation (see examples on the left). In newer settlements, these spaces are disappearing (see examples on the right). (Photos: Nika Cigoj)
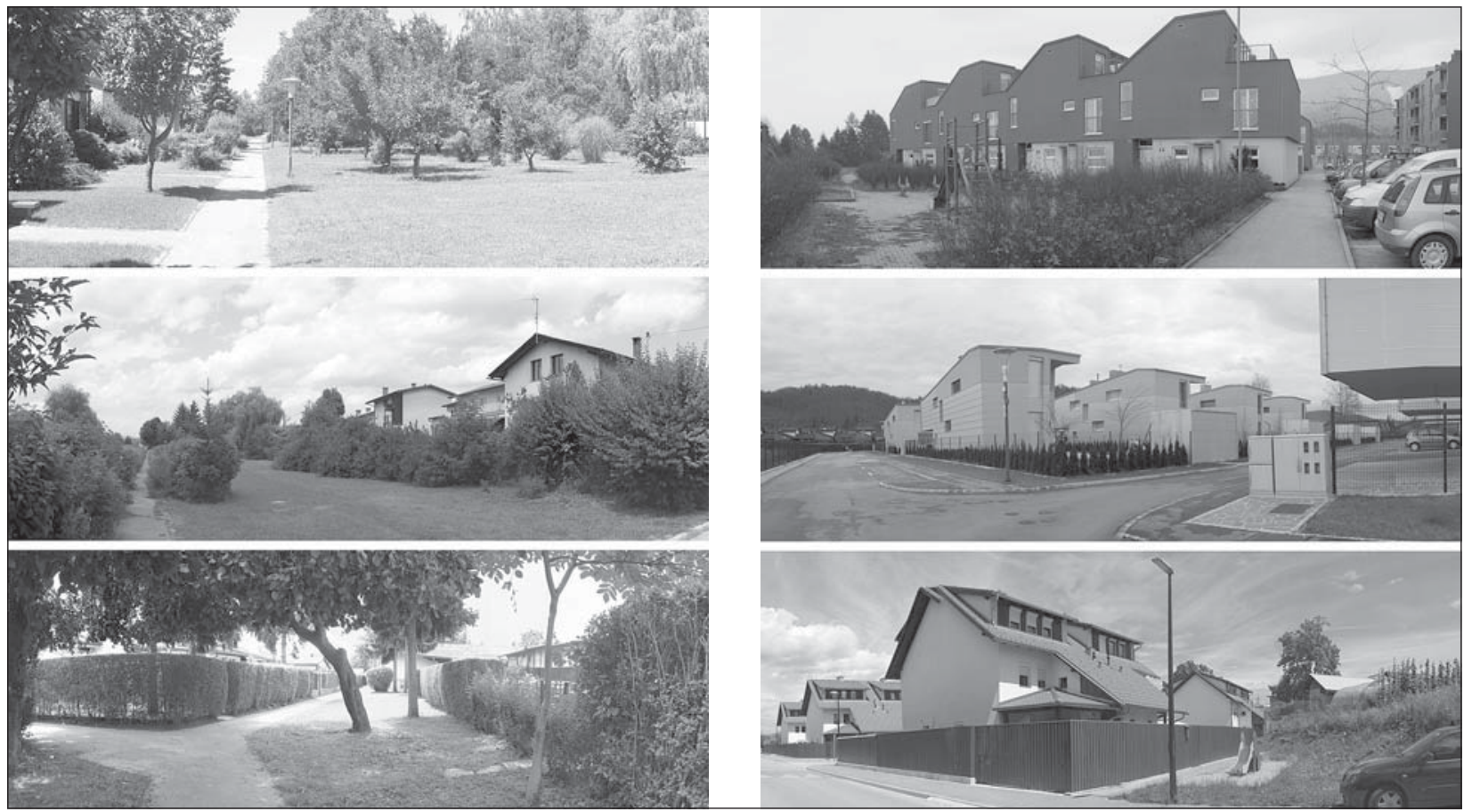

Figure 11: The edges of settlements of single-family houses. Older settlements (see examples on the left) and new settlements (see examples on the right). (Photos: Nika Cigoj)

and vice versa. Smaller open spaces, especially those adjacent to houses at the edge of clusters, are generally used as additional parking areas or even to construct a garage and other extensions. Open areas at the edge of the settlement are usually adopted by inhabitants of the settlement and used as extensions to their own gardens.

\section{Conclusion}

Larger settlements with high-quality open spaces, common planted areas, wider well-structured streets and front gardens, are almost never built today. Instead, smaller settlements on very restricted parcels are being built so that developers can get the highest possible returns from their investments in the real estate market. Open spaces are no longer included in design plans. The urban space is arranged by quotas, minimal conditions, and written regulations. There are too few well-considered building plans that include the construction of housing units and quality green space that would improve both the living conditions within the settlements and the visual appearance. The size and amount of land intended for a new settlement has an essential influence on the project. "In many cases, developers with modest financial means will invest in physically smaller projects and this, along with the limited financial means, will conspire against the construction of a quality living environment" (Simoneti and Vertelj Nared, 2006: 28). This conclusion was confirmed by the results of the present comparative analysis. 
Concurrent with this general worsening of living conditions, there has also been a reduction in the amount that the professional and lay public gets involved with the culture of residential dwellings, with the questions of neighbourhoods as a whole, and the integrated relationship between houses and open spaces. Most new research focuses entirely on the structural features of projects, and particularly the economic aspects of various processes, the typological and location preferences of buyers, and very rarely deals with issues of space, design, and appearance (Stanovanjski sklad Republike Slovenije, 2004).

The real estate market in Slovenia is too small and the housing shortage (especially in larger cities) too great for the market to regulate the quality of new construction. Previous urban standards have become obsolete and have been replaced by new modified standards regarding the number of garbage repositories, parking places, technical street elements, etc. Sadly, the previous standards regarding the quantity and quality of open spaces are neither used nor updated. So it is no surprise that older settlements tend to have a better physical appearance than the new ones with their narrow streets, high houses, sidewalks used for parking, and whatever is left over for poorly-conceived common areas. After nearly twenty years of following the logic of the market, it seems clear that market mechanisms do not function in the area of quality construction of residential settlements in Slovenia, or in any case that they do not improve the quality of what is available.

There remains one key dilemma for future urban development and planning: it is the relationship between marketconstruction with its transitional spatial characteristics on the one hand, and, on the other, a set of organized and regulated construction standards that would preserve past solutions with proven quality.

Nika Cigoj, Landscape Architect

Prostorsko načrtovanje Aleš Mlakar s.p.

E-mail: ncigoj@gmail.com

Dr. Davorin Gazvoda, Landscape Architect, Associate Professor Biotechnical Faculty, Department of Landscape Architecture E-mail: davor.gazvoda@bf.uni-lj.si

\footnotetext{
Notes

${ }^{[1]}$ The analysis of single-family house settlements includes 43 settlements in Ljubljana, Maribor, and Novo mesto. The analysis was conducted in the framework of a graduate thesis with the title Singlefamily housing construction in Slovenia after the year 1990 and green open space design (N. Cigoj, mentor: D. Gazvoda) for the Department of Landscape Architecture of the University of Ljubljana's School of Biotechnology. The analysis was conducted using data from the land and building register of May 2007.

${ }^{[2]} \mathrm{d}=$ average distance between units, $\mathrm{h}=$ average height of buildings in analysed settlements.
}

\section{References}

Bevk, M. (1996) Novi trendi v individualni gradnji. Enodružinska hiša v Sloveniji 45-95. List, Glasilo Društva arhitektov Ljubljane, 17(special issue), pp. 80-81.
Bojovič, B. (1984) Pregled nad družbeno politiko stanovanjske gradnje v Jugoslaviji. Aktualni problemi razvoja stanovanjske gradnje v Sloveniji. Arhitektov bilten, Glasilo Društva arhitektov Ljubljane, 68/69 (special issue), pp. 5-7.

Ivanšek, F. (1998) Enodružinska hiša: od prostostoječe hiše k nizki zgoščeni zazidavi. Ljubljana, Ambient.

Koselj, N. (2005) Enodružinska hiša v času slovenskega povojnega modernizma. Hiše (izbor sodobne slovenske stanovanjske arhitekture), 26(5), pp. $36-41$.

Krušec, T., in Žaucer, T. (1998) Leta jasne vizije. Enodružinska hiša v Sloveniji 45-95. Glasilo Društva arhitektov Ljubljane, 17(special issue), pp 61.

Šašek-Divjak, M., Sendi, R., Jakoš, A., and Cirman, A. (2002) Kakovost stanovanjske oskrbe in bivalnega okolja: zaključno poročilo o rezultatih opravljenega raziskovalnega dela na projektu v okviru ciljnih raziskovalnih programov. Ljubljana, Urbanistični inštitut Republike Slovenije.

Simoneti M., and Vertelj Nared, P. (2006) Analiza večstanovanjske gradnje v Ljubljani, in: Gazvoda, D. and Simoneti, M. (eds.) Stanovanjske krajine: trendi, perspektive, pp. 25-33. Ljubljana, Biotehniška fakulteta, Oddelek za krajinsko arhitekturo, Zavod za prostorsko kulturo TrajekT.

Mandič, S., Hlebec, V., Cirman, A., Dimitrovska Andrews, K., Filipovič, M. Kos, D., Sendi, R., and Gnidovec, M. (2006) Stanovanjska anketa. Ljubljana, Fakulteta za družbene vede, Center za proučevanje družbene blaginje.

Stanovanjski sklad Republike Slovenije (2004) Raziskava o varčevanju v nacionalni stanovanjski varčevalni shemi. Ljubljana.

\section{Karel SCHMEIDLER}

\section{Housing and Urban Development trends in Czech republic}

\section{Introduction: Dwelling - Human Living Environment par Excellence}

A residential flat or apartment is the primary and major environment for human life. A home satisfies the basic needs; (space for physiological functions - sleeping, eating, rest and care of family); higher needs (sense of belonging, satisfaction of the need for self-implementation, need for life in an aesthetic environment, etc.); and human needs; thus becoming the means and stimulation for further evolution.

It is a generally recognised fact that home, or dwelling, is one of the major determinants of the quality of life, affecting every dimension of both psychical and social health. The quality of dwelling affects mental peace and family life, as well as occupational and educational accomplishment. In the same way, a dwelling deficit is reflected in all of the abovementioned areas. Dwelling demand is increasing due to the deep demographic and social changes our society is now facing. This is why the issue of the $21^{\text {st }}$ century dwelling requires a multi-disciplinary approach. 